1110

\title{
ジェットエンジン用エアーブラスト式噴射弁の 微粒化用空気供給路の形状が噴霧特性に及ぼす影響 \\ Effect of Shapes of Supplying Passage for Atomizing Air of Air-Blast Atomizer for Jet Engine on Spray Characteristics
}

\author{
正玉木 伸茂 (近大工), ○学 早坂 大哉（近大院）
}

Nobushige TAMAKI, Kinki University, 1 Takaya Umenobe, Higashihiroshima-shi, Hiroshima, 739-2116, Japan Hiroya HAYASAKA, Kinki University, 1 Takaya Umenobe, Higashihiroshima-shi, Hiroshima, 739-2116, Japan

\begin{abstract}
Emission of nitrogen oxides (NOx) caused by exhaust gas from airplane is computed approximately $60 \%$ at high-altitude. Lean premixed-prevaporized combustion is given for one of methods of NOx reduction in jet engines. Improvement of spray characteristics before combustion is important for fuel injection of jet engine, which is leaded to redaction of exhaust gas emission at high-load conditions and high-dispersion of fuel. However, air-blast atomizer has the following characteristics that velocity of atomizing air decreases with an increase in rapidly large droplets of spray. Therefore, it is required that uniform and small droplets are obtained independent of atomizing air flow rate. The purpose of this study is that uniform and small droplets are obtained under low atomizing air velocity, to improve spray characteristics and homogeneous droplets is generated at wide region of spray. It was investigated that effects of shapes of supplying passage for atomizing air of air-blast atomizer on spray characteristics. As a results, it was cleared that excellent spray characteristics, that is, large spray angle of about $140 \mathrm{deg}$. and relatively small Sauter mean diameter of about $40 \mu \mathrm{m}$, was obtained by using the air-blast atomizer which was designed in this study.
\end{abstract}

Key words: Jet Engine, Atomization,

\section{1. 緒言}

高空における窒素酸化物 $(\mathrm{NOx})$ の約 6 割が航空機に起因す ると言われている(1), (2). ジェットエンジンの NOx 低減方法 の一つとして, 予蒸発予混合による希薄然焼が挙げられ(1), (2), 燃料が燃焼する前の噴霧特性の改善が, ジェットエンジンの 燃焼に適した燃料噴霧の形成に際して重要である。

ジェットエンジン用燃料噴射弁は，エアーブラスト式噴射 弁が広く用いられており, 燃料の空間分散性が高く, 高負荷 条件においても黒煙の生成が少ないという特徽がある(1), (2). しかし, 微粒化用空気の流速が遅くなると, 噴霧粒径が急激 に大きくなるという特徵があるため, 微粒化用空気流量によ らず, 均一微細な噴霧液滴を得ることが求められている.

本研究の目的は, 噴霧の微粒化に際し, 省動力の観点から, 微粒化用空気流速が遅い条件においても, 急激に噴霧粒径が 大きくならず, 均一微細な噴霧液滴が得られ，均質な噴霧液 滴が広範囲に生成されるように, 噴霧特性を改善することで ある. そこで, 噴射弁の微粒化用空気供給路の形状を変化さ せ，噴霧特性に及ぼす影響を調べた。

\section{2. 実験装置および方法}

供試液体は水道水を使用し，大形空気コンプレッサで加圧 した水と微粒化用空気を噴射弁出口付近で混合させて大気圧 雾囲気下に連続噴射した. 水の質量流量 $\mathrm{M}_{\mathrm{l}}$ は $4.0 \mathrm{~g} / \mathrm{s}, 6.0 \mathrm{~g} / \mathrm{s}$, 微粒化用空気の質量流量 $\mathrm{M}_{\mathrm{a}}$ は $1.0 \mathrm{~g} / \mathrm{s}$ から $2.5 \mathrm{~g} / \mathrm{s}$ まで変化 させ，噴霧の微粒化状態を観察した.

また，噴霧粒径は，フランホーファー回析法による粒度分 布解析装置を用いて測定し, ザウタ平均粒径で評価した.

\section{3. 噴射弁の設計}

図 1 に本研究で設計・製作した噴射弁の一例の概略を示す. 本研究において, 微粒化用空気の旋回部が噴射弁の中心軸に 近い所 (以下, 内側空気旋回部之称す. 図 1 中, A-A 断面), 噴射弁の中心軸から離れた所 (以下, 外側空気旋回部と称す. 同, B-B 断面)の微粒化用空気供給路の断面形状を面積一定の 状態で変化させた. 微粒化用空気供給路の断面積は $\mathrm{A}=\mathbf{2 . 2 5}$ $\mathrm{mm}^{2}\left(\mathrm{~b} \times \mathrm{h}=1.5 \times 1.5 \mathrm{~mm}^{2}\right.$, 以下, 正方形と称す)を基準とし
Fuel Injection, Swirl, Air-Blast Atomizer

て一定とし，それぞれ $\mathrm{b} \times \mathrm{h}=1.0 \times 2.25 \mathrm{~mm}^{2}$ (以下，縦長の長 方形と称す), $\mathrm{b} \times \mathrm{h}=\mathbf{2 . 2 5} \times 1.0 \mathrm{~mm}^{2}$ (以下，横長の長方形と称 す)の 3 種類の断面形状の噴射弁を用い, 断面形状が噴霧特性 に及ぼす影響について調べた。

\section{4. 実験結果および考察}

\section{1 微粒化用空気供給路の形状が噴霧特性に及ぼす影響}

図 2 に微粒化用空気供給路の形状が噴霧の微粒化に及ぼす 影響を示し, 図 3 に微粒化用空気供給路の形状がザウ夕平均 粒径に及ぼす影響を示す. 断面形状が横長の長方形の噴射弁

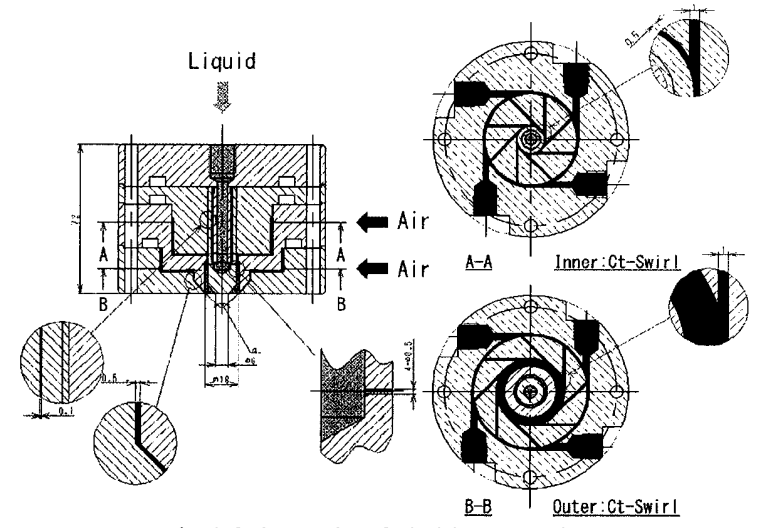

Fig.1 Schematic of air-blast atomizer.

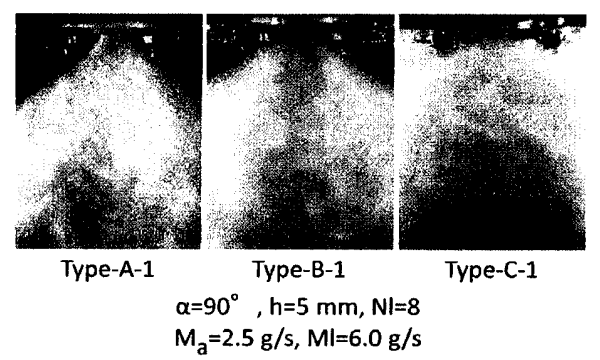

Fig.2 Effect of shapes of supplying passage for atomizing air on atomization of spray. 
の噴霧角が $180^{\circ}$ に達したため, ザウタ平均粒径の測定ができ なかった．断面形状が繸長の長方形の噴射弁 (Type-B-1) は, 正方形の噴射弁 (Type-A-1) より大きな噴霧角が得られ(約 $130^{\circ} \sim 140^{\circ}$ ), 約 $40 \mu \mathrm{m}$ のザウタ平均粒径が得られている.

\section{2 外側の微粒化用空気供給路の形状が噴霧特性に及ぼす 影響}

図 4 に外側の微粒化用空気供給路の形状が噴霧角に及ぼす 影響を示し, 図 5 に外側の微粒化用空気供給路の形状がザウ 夕平均粒径に及ぼす影響を示す。この比較は, 4.1 節の結果 より，断面形状が縦長の長方形の噴射弁を用いると，良好な 噴霧特性が得られたため, これを基準として用いた。 内側微 粒化用空気供給路の形状を縦長の長方形のまま変化させず, 外側微粒化用空気供給路の形状を変化させた。

図 4 より, 外側微粒化用空気供給路の形状が繸長の長方形 の噴射弁 (Type-B-1) は，正方形の噴射弁 (Type-B-2) と横長の 長方形の噴射弁 (Type-B-3) より大きな噴霧角が得られ, 図 5 より，小さなザウタ平均粒径が得られている.

\section{3 内側の微粒化用空気供給路の形状が噴霧特性に及ぼす 影響}

図 6 に内側の微粒化用空気供給路の形状がザウ夕平均粒径 に及ぼす影響を示す。この比較は，4.2 節の結果より，外側 の微粒化用空気供給路の断面形状が縦長の長方形の噴射弁の 方が良好な噴霧特性が得られたため，これを基準として用い た. 外側の微粒化用空気供給路の形状を縦長の長方形のまま 変化させず, 内側の微粒化用空気供給路の形状を変化させた.

図 6 より, 内側の微粒化用空気供給路の形状が緹長の長方 形の噴射弁 (Type-B-1) は， 正方形の噴射弁より小さなザウタ 平均粒径が得られている。

\section{4 噴霧半径方向における粒度分布}

図 7 に噴霧中心軸から半径方向におけるザウ夕平均粒径に 及ぼす影響を示す. 4.1 節から 4.3 節の結果より, 外側の微粒 化用空気供給路, 内側の微粒化用空気供給路ともに断面形状 が縦長の長方形の噴射弁が, 最も良好な噴霧特性が得られた.

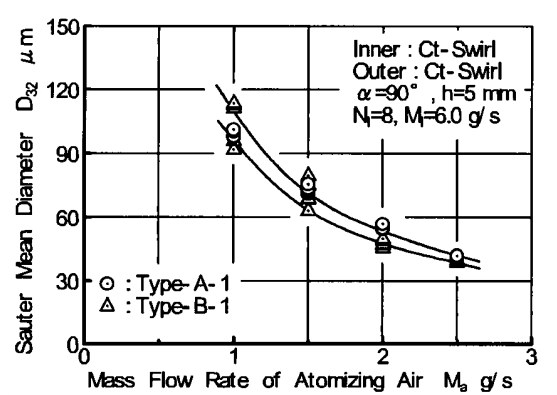

Fig.3 Effect of shapes of supplying passage for atomizing air on Sauter mean diameter.

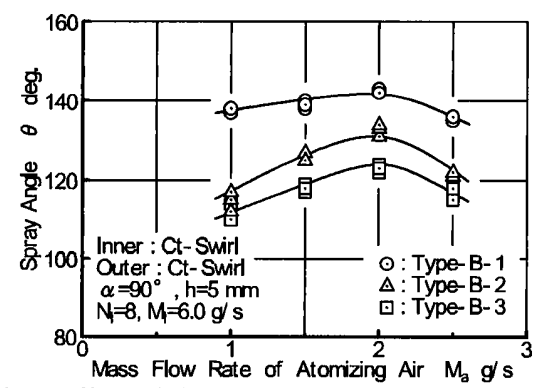

Fig.4 Effect of shapes of supplying passage for atomizing air on spray angle.

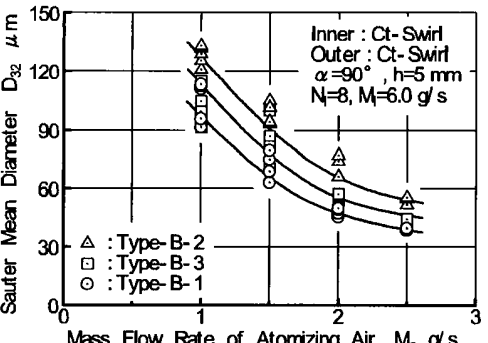

Fig. 5 Effect of shapes of supplying passage for atomizing air on Sauter mean diameter.

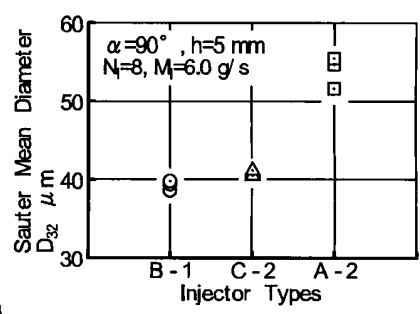

Fig.6 Effect of shapes of supplying passage for atomizing air on Sauter mean diameter.

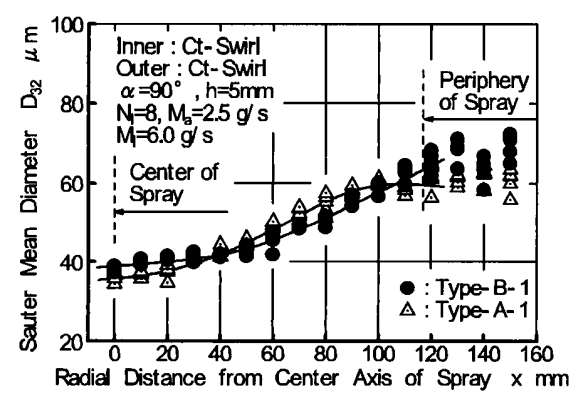

Fig.7 Variations of Sauter mean diameter at radial distance from center axis of spray.

そこで，噴霧中心軸上の一点のみでなく，噴霧半径方向にお ける噴霧液滴の均質性について調べた。

断面形状が正方形の噴射弁に比べ, 縦長の長方形の噴射弁 は，噴霧中心付近 $(x=0 \sim x \doteqdot 40 \mathrm{~mm})$ においてほぼ同じ粒径が 得られていることから，ほぼ均質な噴霧液滴が得られている ことがわかる。ささらに噴霧中心軸から離れた位置において $(x>30 \mathrm{~mm})$, 平均粒径は徐々に大きくなっていくが, 噴霧外 縁に近い $\mathrm{x}=80 \sim \mathrm{x} \fallingdotseq 120 \mathrm{~mm}$ における平均粒径は, 噴霧中心付 近の平均粒径の約 2 倍大きくなっている程度であり, 急激な 平均粒径の増加は見られないため, ほぼ均質な噴霧が得られ ていると考える。

5. 結言

（1）噴射弁の内側の微粒化用空気供給路，外側の微粒化用 空気供給路ともに，断面形状が縦長の長方形の噴射弁 の噴霧角が大きく, 約 $130^{\circ} \sim 140^{\circ}$, 約 $40 \mu \mathrm{m}$ のザウタ 平均粒径が得られた。

（2）内側の微粒化用空気供給路，外側の微粒化用空気供給 路ともに，断面形状が縦長の長方形の噴射弁は，比較 的幅広い噴霧半径方向において，ほぼ同じ平均粒径が 得られ，ほぼ均質な液滴が存在する噴霧が得られた。

\section{参考文献}

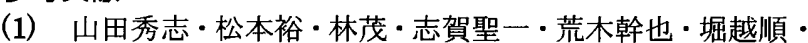
中村壽雄・小保方富夫，ジェットエンジンバーナ用噴射 弁に対する壁面衝突圧力微粒化の効果, 日本機械学会論 文集 (B 編)， 70 巻，700 号，(2004)，233-239.

（2）荒木幹也・堀越順・山田秀志 - 志賀聖一・林茂・ 中村壽 雄・小保方富夫, 衝突噴流型ジェットエンジン燃料噴射 弁の微粒化特性に及ぼす壁面形状の効果, 日本機械学会 論文集（B 編） 71 巻， 710 号，(2005)，184-190. 